\title{
FINDING A HAPPY ENDING FOR FOREIGN INVESTORS: THE ENFORCEMENT OF ARBITRATION AWARDS IN THE PEOPLE'S REPUBLIC OF CHINA
}

\author{
Ellen Reinstein*
}

\section{INTRODUCTION}

Since China opened its doors to foreign trade in 1978, foreign businesspeople have increasingly become involved in Chinese economic development. Foreign investors have now formed partnerships with their Chinese counterparts involving licensing, trade, and direct investment. China, in turn, has embraced this economic development and the benefits it brings to its citizens.

While the global market welcomes the increased business opportunities available in China, foreign investors and privately-owned Chinese companies seek a stable environment and guarantees for fair trade. However, these guarantees are often hard to obtain due to China's cultural skepticism towards the law, its one-party political system, and its underdeveloped court system. Chinese and foreign investors often fear that Chinese courts will not provide adequate protection for their investments.

To avoid the unpredictable and sometimes corrupt Chinese court system, these investors might add a clause to their contracts which specifies that contractual disputes will be settled through arbitration. But when one party refuses to pay the arbitration award, and that party's assets are located in China, enforcement of that award must come through Chinese courts. Investors find themselves in the same court system they initially sought to avoid and may encounter tremendous difficulties in recovering the promised award.

Chinese leaders now recognize the importance of their country's judiciary in furthering economic development, and they have recently promoted several important changes in Chinese law and society. In particular, the highest Chinese court, the Supreme People's Court, passed numerous regulations in the last five years in an attempt to address the longstanding problems faced by foreign parties in the Chinese court system. Legislation now provides for domestic arbitration tribunals to accept arbitrable disputes involving a foreign party, which has increased the competition among, and perhaps the quality of, arbitral bodies in China. In addition, China recently opened the door to permitting the operation of foreign legal programs within its borders, increasing foreign dialogue and training among judges.

With these changes, it is important to determine whether there has been an objective increase in foreigners' ability to enforce arbitration awards in China during the past several decades, or whether these attempts at change are mere posturing and quick-fixes. Equally important, perhaps, is whether foreign 
and Chinese parties sense an increasing faimess with regard to their treatment in China. Indeed, many scholars still insist on a complete overhaul of the Chinese judicial system, claiming that these changes provide a mere "band-aid" for the massive problems continuing to face Chinese courts. Regardless of whether one's view is optimistic or nay-saying, the future development of investment and business relations in China may hinge on China's ability to reform its court system, cultural attitudes, and reputation for successfully enforcing these awards and thereby increasing the confidence of foreign investors.

In Part A of this Article, I will briefly describe the history and development of arbitration in China and the reasons behind its amazing rise in popularity within contracts involving Chinese businesses. In Part B, I will discuss the different types of arbitration awards and the reasons why parties often encounter difficulties enforcing those awards in Chinese courts. In Part C, I will outline the Chinese judicial system and the traditional method of enforcing arbitral awards. Part D will address the attempts made by Chinese judges and lawmakers to confront these challenges, as well as the attempts to measure the improvements, if any, resulting from these changes. Finally, Part $E$ will discuss changes that I believe are necessary to ensure the success of enforcing arbitral awards and possible vehicles to implement those changes.

\section{DEVELOPMENT OF MEDIATION AND ARBITRATION IN CHINA}

Mediation, or conciliation, ${ }^{1}$ has been utilized in China to resolve civil disputes for over two thousand years. China's widespread preference for avoidance of the courts has led to its high utilization of arbitration. As a result, China has one of the biggest and most widely utilized foreign arbitration bodies in the world. China's preference for extra-legal means of resolving disputes is largely due to three factors: Confucian philosophy, an underdeveloped court system, and the influence of communism. ${ }^{2}$ In addition, the relationship-based

*Ms. Reinstein would like to thank Mo Zhang, Adelaide Ferguson, John Smagula, and Bob Reinstein at the Beasley School of Law at Temple University for their incredibly helpful assistance, as well as the Chinese judges and attomeys who kindly contributed to this article. Ms. Reinstein is currently an associate in litigation at Morrison \& Foerster in Palo Alto, CA. She attended U.C. Berkeley School of Law (Boalt Hall) and clerked for Chief Judge Anthony J. Scirica of the Third Circuit United States Court of Appeals.

1. There is very little distinction between "mediation" and "conciliation." One scholar stated, "The differences between the methods [in mediation and conciliation] are slight and the benefits or drawbacks accruing to either method seem negligible." James T. Peter, Med-Arb in International Arbitration, 8 AM. REV. INT'L ARB. 83, 84 n. 1 (1997)(quoting Erik Langeland, The Viability of Conciliation in International Dispute Resolution, 50 OHO ST. J. ON DISP. RESOL. 34 (1995)).

2. Jun Ge, Mediation, Arbitration and Litigation: Dispute Resolution in the People's Republic of China, 15 UCLA PAC. BASIN L.J. 122, 123 (1996); see also Michael T. Colatrella, Jr., "Court-Performed" Mediation in the People's Republic of China: A Proposed Model to 
systems of mediation provide insight into the extra-judicial means of enforcing arbitration awards, which will be discussed later in this Article.

Mediation is believed to have developed in China due to the influences of Confucian philosophy and social morality. Confucianism is a philosophic model that has dominated Chinese history. Confucius believed that "any conflict or litigation between people brings disharmony, which is harmful to social relationships." 3 Ethical behavior, known as $l i$, was embodied in "moral and customary principles of polite conduct." The alternative, fa, represented law and regulation; Confucius held a low view of the law. ${ }^{5}$ While the law was useful to convict and execute people, Confucius did not believe that fa could teach people "humanity, kindness, compassion and benevolence." ${ }^{, 6}$ Chinese law became mainly penal in nature, with highly developed criminal codes and procedures. ${ }^{7}$ In contrast, civil law was not as common, as people tended to avoid pursuing li-disrupting litigation. ${ }^{8}$ Compromise, or yielding (termed jang), became the preferred method of resolving conflicts, and mediation was widely utilized. ${ }^{9}$

The court system in China has traditionally been inaccessible and inadequate for most Chinese citizens. ${ }^{10}$ The magistrates sometimes had no legal training and were often corrupt. ${ }^{11}$ Litigants generally distrusted the courts, making popular the expression "win your lawsuit and lose your money." Citizens embraced alternative dispute resolution as a way to avoid the corrupt court system.

Furthermore, Chinese leadership has traditionally embraced mediation. Until 1949, the village and family elders of each town generally took responsibility for dispute resolution in China. The elders sought to restore harmony and grant concessions through mediation. ${ }^{13}$ Mao Zedong, the leader of Communist China, agreed with these principles of mediation, believing the promotion of social harmony and the common good of society should be emphasized over individual interests. Disputes were resolved through

Improve the United States Federal District Courts' Mediation Programs, 15 OHo ST. J. ON DisP. RESOL. 391, 396-99 (2000).

3. Robert Perkovich, A Comparative Analysis of Community Mediation in the United States and the People's Republic of China, 10 TEMP. INT'L \& COMP. L.J. 313, 315 (1996).

4. Id. at 314.

5. Urs Martin Lauchli, Cross-cultural Negotiations, with a Special Focus on ADR with the Chinese, 26 WM. MrTCHELL L. REV. 1045, 1059 (2000); see also Perkovich, supra note 3, at 314-315.

6. Lauchli, supra note 5, at 1059.

7. Id. at 1060 .

8. See id.

9. Perkovich, supra note 3, at 315; see also Ge, supra note 2, at 123.

10. Colatrella, supra note 2 , at 397.

11. Id.

12. Id.

13. Amanda Stallard, Joining the Culture Club: Examining Cultural Context When Implementing International Dispute Resolution, 17 OHIO ST. J. ON DiSP. RESOL. 463, 477 (2002). 
mediation by People's Mediation Committees, which also had the responsibility to "educate" the people and help to implement party policy. ${ }^{14}$

Because of these influences, Chinese society does not focus heavily on promulgating individual rights through an adversarial system. Instead, mediation focuses on the good of the whole, seeking to understand the other party's position and reach an agreement beneficial to both parties. ${ }^{15}$ Mediation is also based on social morality, appealing to the parties' reason and emotion rather than to laws or regulations. There are several examples of successful mediations where mediators found creative solutions to the problems based on social morality. Professor Stanley Lubman cites several of these examples:

Two brothers disputed over the division of family property for fourteen years. The mediation committee director engaged in heart-to-heart talks with the brothers, assisted them with their needs and recalled their goodwill in the past. They reconciled and renounced their bitterness, and continued their business relationship. ${ }^{16}$

An eighty-year-old woman intended to commit suicide because none of her four sons would support her. A mediator talked with them many times, but they would not listen to him. The mediator himself took care of the woman for months, and his deeds moved her sons to acknowledge their wrongdoing. They divided responsibility for their mother's care. ${ }^{17}$

Urs Martin Lauchli, an international dispute resolution consultant, also gave several examples of traditional dispute resolution in China:

[I]n one dispute involving the marital problems of a husband and wife, which included allegations of abuse by the wife, the mediator suggested that the couple go to Beijing for a holiday. "The matter was resolved when the husband expressed regret that he abused his wife." In another instance, after mediation, an unmarried woman who had become pregnant agreed to write a "self-criticism" and pay a fine. In a third instance, a grandson was angry with his grandmother over her living

14. Colatrella, supra note 2 , at 399.

15. Stallard, supra note 13 , at 476.

16. Stanley lubman, Bird in a Cage: Legal Reform in China After mao 230, (Stanford University Press) (1999) [hereinafter BIRD IN A CAGE] (quoting Liu Guangan \& Li Cun Peng, Minjian Tiaojie Yu Quanli Baohu (Civil Mediation and the Protection of Rights), in ZOUXIANG QUANLI DE SHIDAI: ZHONGGUO GONGMIN QUANLI FAZHAN YANIIU (TOWARD A TMME OF Rights: A PERSPECTIVE OF THE CIVIL RightS DEVELOPMENT IN CHINA) 285-326 (Xia Yong, ed., (1995)).

17. Id. at 231. 
arrangements. The neighborhood mediation "committee met with the disputants and reminded the grandson that his grandmother, who was ninety-four years old, did not have long to live and that he should therefore try to make her happy."18

Some traditional mediators did not adhere to the rule of law, but instead encouraged creative solutions to fit the individual parties' circumstances.

The use of mediation in China has recently been declining, while arbitration and judicial resolution have become more popular. ${ }^{19}$ With an increase in globalization and an accompanying complexity in the form of disputes, mediation committees may not have the expertise to resolve the dispute or the required jurisdiction over the parties. ${ }^{20}$ Contracts between foreign parties may not involve repeat players, and higher monetary values are at stake. ${ }^{21}$ In addition, Chinese society has become more rights-conscious: parties are using courts to protect their rights and seek compensation for infringement of those rights. ${ }^{22}$

The decline in mediation may correspond to a recent increase in the use of arbitration in China. For most Chinese parties, arbitration strikes an appropriate balance between mediation and litigation. ${ }^{23}$ Arbitration tribunals are viewed as less confrontational than litigation, thus appealing to the Confucian philosophy and Communist principles. ${ }^{24}$ Further, the flexible nature of arbitration can allow parties to resolve disputes more easily. ${ }^{25}$

Many foreigners also prefer arbitration as a fair and efficient vehicle for resolving disputes. Foreign parties might view the Chinese judicial system as lacking the commercial expertise to resolve business contracts, adhering to slow and complex court procedures, and practicing local protectionism, as discussed below. Arbitration is usually cheaper and faster than the court system. ${ }^{26}$ Equally important, foreign investors utilize arbitration clauses in an attempt to

18. See Lauchli, supra note 5, at 1066 (footnotes omitted).

19. Id. at 1067; see also Interview with Wang Chenguang, Dean, Tsinghua University School of Law, in Beijing, China (November 2, 2004)[hereinafter Interview with Wang Chenguang]; Class Action Litigation in China, 111 HARv. L. REv. 1523, 1531 at n. 66 (1998).

20. Interview with Wang Chenguang, supra note 19.

21. Id.

22. Id.

23. Id.

24. Fredrick Brown \& Catherine A. Rogers, The Role of Arbitration in Resolving Transnational Disputes: A Survey of Trends in The People's Republic of China, 15 BERKELEY J. INT'L L. 329, 337 (1997).

25. Id.

26. See Ge Liu \& Alexander Lourie, International Commercial Arbitration in China: History, New Developments, and Current Practice, 28 J. MARShall L. Rev. 539, 539-540 (1995) [hereinafter Liu]. 
avoid the Chinese court system, which is widely perceived as corrupt and ineffective, tending to favor the Chinese party in the dispute. ${ }^{27}$

\section{ARBITRATION BODIES AND AWARDS IN CHINA}

China began to open its borders to international trade in the 1950 s and then to the world in 1978-79. After more than a decade of experimental arbitration, the National People's Congress (NPC) passed the Arbitration Law of the People's Republic of China ("Arbitration Law"), effective September 1, $1995 .^{28}$ The Arbitration Law established uniformity between arbitral bodies, provided a procedural code, set a high standard for arbitration personnel, and gave arbitral awards more finality. ${ }^{29}$ The law also outlined the relationship between arbitral bodies and the courts and defined arbitrable transactions. ${ }^{30}$

\section{A. Awards in China}

Several different types of arbitral awards exist in China: foreign, foreignrelated, and domestic. Foreign arbitral awards are made outside of China, ${ }^{31}$ while foreign-related awards are those made by international arbitration bodies in China and/or awards that involve a foreign element. ${ }^{32}$ A foreign element may include a case where at least one party is a foreign person, organization, or enterprise; the creation, modification or termination of the contract between the parties occurred in a foreign country; or the action was brought in a foreign country. ${ }^{33}$ Domestic awards involve Chinese parties and subject matter relating only to China. These disputes are beyond the scope of this Article, as they are regulated by different laws.

27. Interview with Zhao Shiyan, attorney at law, Jingtian \& Gongcheng, in Beijing, China (Nov. 2, 2004).

28. The $9^{\text {th }}$ Session of the Standing Committee of the $8^{\text {th }}$ National People's Congress adopted the Arbitration Law of the PRC on Aug. 31, 1994. Arbitration law of the PRC, People's Dally (Overseas Edition), Sept. 2, 1994, at 2.

29. Liu, supra note 26 , at $552,554,556$.

30. Id. at $552,554$.

31. Randall Peerenboom, The Evolving Regulatory Framework for Enforcement of Arbitral Awards in the People's Republic of China, 1 AsIAN-PAC. L. \& POL'Y J. 12, 11 (2003) [hereinafter Evolving Regulatory Framework].

32. Id. A dispute between two Chinese parties may be foreign-related when the object of the dispute is outside China or where the legal relationship between the parties was established, modified, or terminated outside China. See also Neil Kaplan, Roundtable on Arbitration and Conciliation Concerning China: HKIAC's Perspective (paper prepared for presentation at the 17th ICCA Conference, May 16-18, 2004) [hereinafter Kaplan]. Mr. Kaplan is the chairman of the Hong Kong International Arbitration Centre.

33. See, Evolving Regulatory Framework, supra note 31, at 11. 


\section{B. Current Arbitration Bodies}

Two main international arbitration bodies in China handle foreign and foreign-related disputes: the China International Economic and Trade Arbitration Commission (CIETAC) and the China Maritime Arbitration Commission (CMAC). ${ }^{34}$ In addition, Chinese domestic arbitration tribunals have greatly expanded within the last decade and now may accept foreign and foreign-related disputes. The rapid and extensive development of these domestic tribunals further demonstrates the demand for this type of forum within China and its importance to the Chinese government.

\section{CIETAC}

CIETAC underwent several changes in name and function before establishing itself as an international arbitration commission. In 1954, the China Council for the Promotion of International Trade (CCPIT) founded the Foreign Trade Arbitration Commission (FTAC) to handle trade disputes. ${ }^{35}$ In 1980, FTAC was renamed the Foreign Economic and Trade Arbitration Commission, as its jurisdiction was broadened to include non-trade economic matters. ${ }^{36}$ Then, in 1988, CCPIT further expanded the body's jurisdiction to encompass disputes arising out of international economics and trade. That same year, it also issued new rules that brought the body's procedures more in line with international practices. Reflecting the increased jurisdiction, CCPIT assigned the arbitration body its current name. ${ }^{37}$

CIETAC is now one of the largest commercial arbitration centers in the world, having arbitrated nearly 8,000 disputes between 1993 and $2003 .^{38}$ This high caseload and popularity is due to several factors. Until 1996, the Chinese government authorized CIETAC as the only international commercial arbitration center in China. ${ }^{39}$ Chinese parties not familiar with international business practices are more likely to name CIETAC as the designated arbitration commission. ${ }^{40}$ In addition, increasing trade with Chinese businesses may correspond with an increase in arbitrable disputes. Finally, Chinese regulations recommend that Chinese parties involved in certain types of disputes apply to CIETAC for arbitration. ${ }^{41}$

34. CMAC, created to resolve maritime disputes, only handles approximately twenty cases per year. Charles K. Harer, Arbitration Fails to Reduce Foreign Investors' Risk in China, 8 PAC. RIM L. \& Pol'y 393 (1999). (quoting China: Courts Handle Maritime Cases, CHINA DAILY, Sept. 22, 1998.).

35. Liu, supra note 26 , at 540 .

36. Id. at 541 .

37. Id.

38. Id. at 541-542.

39. See id. at 541.

40. Id. at 542 .

41. Id. 


\section{Domestic Arbitration Tribunals and the Beijing Arbitration Commission}

CIETAC and other foreign arbitration organizations are now encountering competition for foreign and foreign-related cases from domestic arbitration tribunals. China's current domestic arbitration system was created only ten years ago, through the passage of the Arbitration Law. ${ }^{42}$ Among other things, the Arbitration Law mandated the establishment of local arbitration commissions. ${ }^{43}$ In 1996, the State Council authorized domestic arbitration commissions to accept foreign-related cases. ${ }^{44}$ The location and scope of these commissions have grown tremendously, from seven "trial cities" in 1995 to approximately 170 commissions now operating in cities throughout China. ${ }^{45}$ The commissions vary widely in case experience, expertise among arbitrators, and independence from local government influences. ${ }^{46}$ The commissions located in major cities are reported to be more financially independent.

The Beijing Arbitration Commission (BAC) is considered to be China's "flagship" domestic arbitration institution and is the national focal point for communication and training among the various domestic commissions. ${ }^{47}$ The BAC is reported to be entirely self-sufficient, meeting its operating expenses from arbitration fees. ${ }^{48}$ The BAC accepted 1,029 cases in 2003, and it has accepted over 4,000 cases in total since its inception in $1995 .^{49}$

Although the vast majority of the BAC's cases involve domestic disputes, the cases involving foreign-related disputes and foreign parties are slowly growing. It now actively pursues foreign markets. ${ }^{50}$ The BAC also has specialists in the International Federation of Consulting Engineers (FIDIC) among its arbitrators to address issues in international construction projects, particularly in light of the preparation for the 2008 Olympic Games in Beijing. ${ }^{51}$ In addition, the BAC has an extensive and accessible website,

42. Jerome A. Cohen and Adam Kearney, Domestic Arbitration: The New Beijing Arbitration Commission, in DoING BusINESS IN CHINA, $\S 3.02$, IV-3.2 (Freshfields ed. 2000) [hereinafter New BAC].

43. Id.

44. Evolving Regulatory Framework, supra note 31, at 12.

45. New BAC, supra note 42, at IV-3.2; See also Introduction to the Beijing Arbitration Commission, 17th ICCA Conference (May 16-18, 2004) [hereinafter Introduction to BAC].

46. New BAC, supra note 42 , at IV-3.3.

47. Id. at $I V-3.2$.

48. Id.

49. Introduction to BAC, supra note 45; DONALD ClARKE \& ANGELA DAVIS, DISPUTE RESOlUtion IN ChINA: THE ARBITRATION OPTION, China (2000), available at http://www.asialaw.com/bookstore/china2000/ [hereinafter CLARKE].

50. Wang Hongsong, Beijing Arbitration Commission 2001 Work Summary and 2002 Work Plan, available at http://www.bjac.org.cn/en/brow.asp?id=133 (last visited October 10, 2005) [hereinafter 2001 Work Summary]; see also Introduction to BAC, supra note 45 ("The BAC has also been attaching prime importance to the building of arbitrator systems with reference to international practices.").

51. See Introduction to the BAC, supra note 50. 
translated in English, that highlights its latest developments, including mandatory training sessions for newly appointed and untrained arbitrators, a recently compiled Arbitrators' Manual, and a publication stating the ethical standards for BAC arbitrators. ${ }^{52}$ The BAC also appears willing to adjust its procedures to accommodate foreign parties. For example, after foreign parties objected to the BAC's limitation that only two attorneys representing a party are allowed in the courtroom at a time, the BAC agreed to relax that requirement. $^{53}$

Arbitrating with the BAC might be preferable for several reasons. The BAC claims that the average duration of cases from formation to conclusion is a mere seventy-nine days. ${ }^{54}$ In addition, parties might specify arbitration with a domestic tribunal that contains arbitrators they are familiar with or arbitrators with a particular specialization. ${ }^{55}$

\section{Competition Between CIETAC and BAC}

Given the recent addition of quality domestic tribunals such as the BAC, CIETAC faces stiff competition over foreign and foreign-related disputes. In addition, CIETAC practices have recently come under attack by scholars, particularly law professor and practitioner Jerome Cohen of New York University. CIETAC, realizing the necessity of addressing these critiques, has adopted some of the changes suggested by Professor Cohen, while disputing the necessity of other changes.

Professor Cohen has strongly criticized CIETAC practices for a variety of reasons. He claims that CIETAC permits the appointment of staff persons as presiding arbitrators, which could arguably allow for the exercise of administrative influence and control over the panel's decision. ${ }^{56}$ It appears Professor Cohen's critique has been heeded, for Cao Lijun, a CIETAC arbitrator, maintains that CIETAC now requires that "all staff members . . . decline appointment by parties unless it is a joint appointment as a sole or presiding arbitrator." $57 \mathrm{Mr}$. Cao further asserts that CIETAC staff members can only be appointed by the CIETAC chairman when the parties have defaulted in making an appointment. ${ }^{58}$

52. Id.; see also Ethical Standards for Arbitrators of the Beijing Arbitration Commission, available at http://www.bjac.org.cn/en/brow.asp?id=699 (May 26, 2004).

53. New BAC, supra note 42 , at 3.15 .

54. Introduction to BAC, supra note 45.

55. Interview with Wang Chenguang, supra note 19; see also Introduction to BAC, supra note 45; see 2001 Work Summary, supra note 50.

56. Jerome A. Cohen, International Commercial Arbitration in China: Some Thoughts from Experience, 3 (paper prepared for presentation at the International Economic Law and China in its Economic Transition Joint Conference (Nov. 4-5, 2004)) [hereinafter Int'l Address].

57. E-mail from Cao Lijun, Arbitrator and Staff Member, CIETAC, China, to Ellen Reinstein (Jan. 31, 2005, 11:31 PST)(on file with author) [hereinafter Cao e-mail 1/31/05].

58. $I d$. 
Professor Cohen also questions CIETAC's current practice of allowing its arbitrators to serve as advocates in other CIETAC cases on the basis that it breeds too much familiarity and diminishes institutional integrity, particularly given China's existing "guanxi" practices. 59 Instead, he suggests, CIETAC should amend its rules, as the BAC has, to require all those serving as arbitrators to cease serving as advocates in other CIETAC cases. ${ }^{60}$ CIETAC has not directly addressed this concern. However, Dr. Wang Shengchang, Vice-Chairman of CIETAC, states that the statistics on the outcome of decisions by CIETAC arbitrators contradict Professor Cohen's claim of any resulting bias from CIETAC tribunals against foreign parties. ${ }^{61}$

Professor Cohen has also critiqued CIETAC for permitting arbitrators to assign the drafting of published opinions to the CIETAC staff. ${ }^{62}$ Wang Chenguang, Dean of Tsinghua University and a member of the Advisory Committee to the Supreme People's Court, suggests that this situation is being addressed by CIETAC, as the CIETAC administration is now asking arbitrators to spend more time on the hearings, meeting two or three times if necessary, and to write the award judgments themselves. ${ }^{63}$ Indeed, Mr. Cao claims that CIETAC encourages the tribunal to play a larger role in administering the case and now requires members of the tribunal, in particular the presiding arbitrator, to draft the award. ${ }^{64}$

Aside from these procedural issues, CIETAC and the BAC offer their own advantages and disadvantages. CIETAC is well-established in the business community and is generally well-respected, although there has been a slowly growing undercurrent of dissent from some foreign lawyers. ${ }^{65}$ For almost twenty years, it has relied on income earned from administrative fees, instead of receiving funds from the government, demonstrating its independence from the government. ${ }^{66}$ Parties are able to designate a specific foreign arbitrator to sit on CIETAC's panel of arbitrators, which includes 146 foreign nationals from nearly 30 different countries. ${ }^{67}$ In comparison, the BAC claims to have "Chinese and foreign professional" experts, but it is uncertain

59. See Int'l Address, supra note 56, at 2,4. Professor Cohen also notes that, while CIETAC will honor an arbitration clause specifying that the presiding arbitrator be from a third country, CIETAC does not advertise or encourage this option.

60. Id. at 4.

61. See Michael J. Moser, Roundtable on Arbitration and Conciliation Concerning China: Commentary (paper prepared for the $17^{\text {th }}$ ICCA Conference, May 16-18, 2004) [hereinafter Roundtable]. Mr. Moser is a partner at Freshfields Bruckhaus Deringer.

62. Int'l Address, supra note 56 , at 10 . In comparison, the BAC requires arbitrators to do their own work.

63. Interview with Wang Chenguang, supra note 19.

64. Cao e-mail 1/31/05, supra note 57.

65. Id.

66. See Roundtable, supra note 61 .

67. Id. at $\$ 1.4$ 
whether the arbitrators are actually from foreign countries or are merely Chinese arbitrators authorized to hear foreign disputes. ${ }^{68}$

CIETAC claims to have new areas of expertise that could assist the resolution of certain types of contracts, having established the Domain Name Dispute Resolution Center in 2001 and the Future Transaction Dispute Resolution Center in 2003. ${ }^{69}$ CIETAC officials claim that courts will give deference to CIETAC awards, given CIETAC's forty-year history and the courts' greater familiarity with the institution. ${ }^{70}$ Furthermore, Chenguang mentioned that enforcement of CIETAC awards can be less problematic than enforcement of domestic awards, as the Supreme People's Court interpretations are more clearly applicable to CIETAC awards than to domestic awards. ${ }^{71}$

On the other hand, the BAC offers several potentially persuasive advantages over CIETAC, particularly for smaller commercial disputes. ${ }^{72}$ The BAC's procedure is relatively speedy, with an average duration of two and a half months from the beginning to the conclusion of a case. ${ }^{73}$ In addition, fees for BAC arbitration are generally lower than fees for CIETAC. ${ }^{74}$ Choosing the BAC could benefit a smaller company that is already familiar with and specifies an arbitrator listed with the BAC.

Currently, there are no statistics indicating whether parties involved in foreign disputes are staying with CIETAC arbitration or switching to domestic tribunals, such as the BAC. It appears CIETAC has accepted fewer overall cases as a result of the 1996 Notice, which could potentially be caused by competition from the local arbitration commissions. ${ }^{75}$ However, statistics are not available to decipher whether those involved in foreign disputes have chosen not to arbitrate with CIETAC, or whether they are specifying other international arbitration bodies or other dispute resolution methods, such as mediation.

68. See Introduction to BAC, supra note 45 ; New BAC, supra note $42, \$ 3.03$ at IV-3.5 ("Although there are currently six individuals from Hong Kong and two from Taiwan on the $\mathrm{BAC}$ roster, there are no foreign arbitrators on the list and no plans to appoint foreign arbitrators in the foreseeable future, primarily due to financial constraints.").

69. See Roundtable, supra note 61.

70. See Cao e-mail, supra note 57. Cao Lijun asserts:

It is true that CIETAC awards, whether domestic ones or foreign-related ones, receive more deference in the enforcement or annulment proceedings. Most of CIETAC arbitrators are distinguished legal scholars, practitioners or retired judges and their qualities are reflected in their decision-making. CIETAC is the most reputable institution in China. The awards are also subject to the scrutiny of CIETAC before they are officially rendered. I believe all these contribute to the deference.

71. See Interview with Wang Chenguang, supra note 19.

72. See New BAC, supra note $42, \$ 3.10$ at IV-3.22.

73. See Introduction to BAC, supra note 45 .

74. See New BAC, supra note $42, \$ 3.10$ at IV-3.22.

75. Mauricio J. Claver-Carone, Post-Handover Recognition and Enforcement of Arbitral Awards between Mainland China and Hong Kong SAR: 1999 Agreement vs. New York Convention, 33 LAW \& POL'Y INT'L BUS. 369, 392 (2002). 


\section{Ad-hoc Bodies}

Chinese courts appear to have taken a new approach to the final type of arbitration within China, ad hoc arbitration. Chinese law has traditionally held as void arbitral agreements issued by a body that was not a recognized arbitral institution. ${ }^{76}$ Furthermore, Article 18 of the Chinese Arbitration Law provides that if an arbitration clause does not select an arbitration commission or does not reach a supplementary agreement regarding the commission which is chosen, the arbitration agreement will be void. ${ }^{77}$ Due to the Convention on the Recognition and Enforcement of Foreign Arbitral Awards (New York Convention), Chinese courts usually recognize and enforce ad hoc awards made in Convention States. ${ }^{78}$ However, it is unclear whether Chinese courts will acknowledge and enforce ad hoc awards made within Mainland China. ${ }^{79}$ Professor Randall Peerenboom predicts that CIETAC will oppose acknowledgement of ad hoc awards in an attempt to ensure its dominance in foreign-related arbitration cases in China. ${ }^{80}$

It is less certain whether arbitration clauses calling for "arbitration under UNCITRAL rules in China" may be enforced. ${ }^{81}$ One unpublished, internal document of the Supreme People's Court (SPC) stated that an arbitration clause of this nature is ad hoc arbitration and is, therefore, unenforceable. ${ }^{82}$ On the other hand, arbitration clauses that specify arbitration in China under the auspices of the International Chamber of Commerce and the Singapore International Arbitration Centre are supposedly valid and enforceable. ${ }^{83}$

It appears that the law in China is shifting towards a more open approach to ad hoc arbitrations. Article 27 of the December 31, 2003 draft of the Provisions of the Supreme People's Court Regarding People's Courts' Handling of Arbitration Cases Involving Foreign Elements and Cases Arbitrated Abroad states:

An arbitration agreement is invalid in which the parties have agreed to submit their disputes to ad hoc arbitration, except when the parties concerned are citizens of member countries to the 1958 United Nations Convention on the Recognitions and Enforcement of Foreign Arbitral Awards and the laws of such countries do not prohibit ad hoc arbitration. ${ }^{84}$

76. See Kaplan, supra note 32.

77. Claver-Carone, supra note 75 , at 390.

78. Evolving Regulatory Framework, supra note 31, at 13.

79. Id.

80. Id.

81. See ClARKE, supra note 49 , at 9.

82. Id.

83. Id.

84. Kaplan, supra note 32 , at 6 . 
Since China does not officially allow ad hoc arbitration, it is assumed that this provision applies only when both parties are citizens of foreign countries. However, some have argued that the SPC provision would only make sense if it were to also apply to the Chinese party. ${ }^{85}$ This could indicate China's increased willingness to permit ad hoc arbitrations and enforcement of resulting agreements within China. ${ }^{86}$

\section{GENERAL PROCEDURE FOR ENFORCEMENT OF ARBITRATION AWARDS IN CHINA}

Arbitration awards are considered final and enforceable. ${ }^{87}$ If a party fails to pay an arbitration award, the party receiving the award must seek enforcement in the court system where the assets are located. For many parties, this leads to the situation they fear most - dealing with the Chinese court system.

\section{A. Chinese Court Structure}

A brief overview of the structure of the court system within China is necessary to understand the problems of enforcement, as well as potential solutions. There are about three thousand county-level Local People's Courts. ${ }^{88}$ Above this are 389 Intermediate Level People's Courts (IPC), which sit in provincially-administered cities and centrally-administered cities. ${ }^{89}$ The Local and Intermediate Level Courts have separate enforcement chambers. At the next level, there are thirty Higher People's Courts (HPC), one for each province, autonomous region, and centrally-administered city. ${ }^{90}$ Finally, the Supreme People's Court (SPC) is the highest court in China. ${ }^{91}$

In addition, each court has an Adjudication Committee, which is comprised of the president of the court, the vice-president, the head of specialized chambers, and regular judges. ${ }^{92}$ These Committees, usually comprised of members of the CCP, advise individual judges in cases deemed to be important. ${ }^{93}$ This further detracts from judicial independence.

85. Id.

86. Indeed, there are isolated cases where courts in China have upheld ad hoc awards. For example, in 1990 the Guangzhou Maritime Court enforced three ad hoc awards made in London in Ocean Shipping Company. See John ShIJIAN Mo, ARbITRATION LaW IN ChINA 427 (Sweet \& Maxwell ed., 2001) (discussing Guangzhou v. Marships of Connecticut).

87. BIRD IN A CAGE, supra note 16, at 246.

88. Jeffrey W. Berkman, Intellectual Property Rights in the P.R.C.: Impediments to Protection and the Need For the Rule of Law, 15 UCLA PAC. BASIN L.J. 1, 22 (Fall 1996).

89. Id.

90. Id.

91. Id.

92. Id.

93. Id. 


\section{B. Civil Procedure Law}

Before 1982, China had no legal basis for enforcing foreign-related arbitral awards. ${ }^{94}$ The awards depended on voluntary compliance by the losing party. ${ }^{95}$ The Civil Procedure Law (CPL), passed in 1982, provided a legal basis for compulsory enforcement of arbitration awards. Article 195 of the CPL specified:

When one of the parties concerned fails to comply with a ruling made by a foreign affairs arbitration organization of the PRC, the other party may request that the ruling be enforced in accordance with the provisions of this article by the courts at the place where the arbitration organization is located or where the property is located. ${ }^{96}$

The article did not consider ad hoc awards, and it did not contain a provision for the refusal of enforcement; all awards were final and enforceable. ${ }^{97}$ The court would not perform the limited review allowed under the New York Convention, but was merely instructed to execute the award. ${ }^{98}$ In addition, parties could seek enforcement at the place of arbitration or where the assets were located. ${ }^{99}$

The procedure for enforcing foreign arbitral awards under the $1982 \mathrm{CPL}$ proved to be fairly confusing. PRC courts could only enforce final judgments or rulings, so arbitral awards had to be converted into a judgment or ruling to be enforceable. ${ }^{100}$ Moreover, only a foreign court could request the enforcement of an award, not the victorious party, and some foreign courts did not have the jurisdiction to make this request. ${ }^{101}$ The PRC court could also refuse to enforce the judgment if it would violate national or social interests. ${ }^{102}$ Due largely to this confusion, no parties successfully enforced a foreign arbitral award under Article 195. ${ }^{103}$

In December 1986, the NPC determined that China would join the New York Convention. ${ }^{104}$ China made the following declaration: First, the People's Republic of China will "apply the Convention" to the recognition and enforcement of arbitral awards rendered in the territory of another Contracting

94. See Evolving Regulatory Framework, supra note 31, at 13.

95. Id.

96. Id.

97. Id. at 14 .

98. Id.

99. Id.

100. Id.

101. Id.

102. Id. at 14-15.

103. Id. at 15.

104. Id. 
State "only on the basis of reciprocity"; and second, the People's Republic of China will apply the Convention only to disputes which have, according to the laws of the People's Republic of China, been determined as arising out of "commercial legal relationships of a contractual nature or a non-contractual nature". ${ }^{105}$

Once China became a party of the New York Convention, it was subject to the reciprocity and commercial reservations quoted above. ${ }^{106}$ Over 100 countries, including most of China's major trading partners, are now parties to the New York Convention. ${ }^{107}$ Reciprocity now applies to nearly all arbitral awards involving Chinese parties. ${ }^{108}$

In 1991, the NPC amended the 1982 CPL, specifying that courts must handle enforcement pursuant to international treaties to which China is a party. ${ }^{109}$ The revision also provided standards for refusal to enforce domestic and foreign-related awards, to be discussed later in the paper. In addition, the revisions no longer provided jurisdiction based on the place of arbitration. ${ }^{110}$ The venue for foreign-related awards can only be the respondent's legal domicile or where the property is located. ${ }^{111}$

\section{Obstacles to Enforcement of Foreign Arbitration Awards} it." "12

"An arbitral award is only as good as the court that is asked to enforce

Chinese courts have the statutory authority to enforce arbitral awards. Whether based on anecdotal information, one or two poorly decided enforcement decisions, or a prevalent refusal by Chinese courts to enforce foreign awards, many foreign investors and commentators report that enforcement of foreign awards in China is often difficult or impossible. ${ }^{113}$

105. Id.

106. Id.

107. Id. at 27.

108. Id. ("To enforce under the principle of reciprocity would require that the award be rendered in a nation that was not a party to the New York Convention but had previously recognized and enforced arbitral awards or judicial judgments issued in the PRC. More than 100 countries are now parties to the New York Convention, including most of China's major trading partners.").

109. Liu, supra note 26 , at 549-51.

110. Evolving Regulatory Framework, supra note 31, at 18.

111. Id.

112. Roundtable, supra note 61 , at $\$ 3$.

113. See, e.g., Greg Rushford, Chinese Arbitration: Can It Be Trusted?, ASIAN WaLLST.J., Nov. 29, 1999; Harer, supra note 34, at 395 ("If the Chinese party to an arbitration agreement does not voluntarily participate and comply with an award, the arbitration agreement can be a no-win situation for a foreign party transacting business with a Chinese entity."); But see Sally A. Harpole, Following Through on Arbitration, ChINA Bus. Rev., Sept.-Oct. 1998, at 33-38, available at http://www.chinabusinessreview.com/public/9809/harpole.html. 
Combating this perception, PRC sources have cited to positive anecdotal information to downplay enforcement challenges. ${ }^{114}$

The difficulty in verifying the accuracy of these foreign reports is exacerbated by the lack of concrete measurable data. Several attempts have been made to ascertain the likelihood of successfully enforcing arbitration awards. In 1997, the Arbitration Research Institute (ARI) of the China Chamber of Commerce surveyed 134 applications made to People's Courts between 1991 and 1996 for enforcement of CIETAC awards. ${ }^{115}$ According to this survey, ninety-seven awards were enforced and thirty-seven were denied enforcement by the courts. ${ }^{116}$ The survey cited the principal reasons for denial of the awards. In several cases, the validity of the arbitration agreement itself was in question. ${ }^{117}$ In other cases, parties were effectively denied the opportunity to participate in the arbitration proceedings. ${ }^{118}$ In yet other cases, the courts found that the arbitrators exceeded their authority by acting outside the jurisdictional limits of the arbitration body or the scope of the arbitration agreement. $^{119}$

Professor Randall Peerenboom claims the ARI's survey suffered from "methodological problems and poor responsiveness by the courts." $20 \mathrm{He}$ conducted his own independent survey of eighty-nine CIETAC and foreign arbitral award enforcement cases. ${ }^{121}$ Calculating enforcement rates from seventy-two of these cases, Peerenboom painted a substantially bleaker picture than the official CIETAC statistics, finding that $52 \%$ of the foreign awards and $47 \%$ of the CIETAC awards were enforced. ${ }^{122}$ Investors could expect to recover 50 to $75 \%$ of the award amount in $34 \%$ of the cases and half of the award amount in over $40 \%$ of the cases. ${ }^{123}$

What accounts for this relatively low recovery rate for arbitration awards? Many different factors may be involved, including the lack of an independent Chinese judicial system, corruption, and the insolvency of Chinese parties.

114. See, e.g., Wang Guiguo, One Country, Two Arbitration Systems: Recognition and Enforcement of Arbitral Awards in Hong Kong and China, 14 J. INT'L ARB. 5-42 (Mar. 1997) (claiming there are few reported cases where courts have refused to enforce a convention award).

115. Cheng Dejun et al., International Arbitration in the People's Republic of CHINA 129 (Butterworths Asia 2000).

116. Id.

117. Id.

118. Id. at 130 .

119. Id.

120. Randall Peerenboom, Seek Truth From Facts: An Empirical Study of Enforcement of Arbitral Awards in the PRC, 49 AM. J. COMP. L. 249, 251 (2001) [hereinafter Seek Truth].

121. Id. at 252.

122. Id. at $252,254$.

123. Id. at 254 . 


\section{Lack of an Independent Judiciary: Influence from CCP and Local Government Officials}

The Constitution of the PRC, effective since 1982, specifies that China is a unitary state based on a system of parliamentary supremacy. ${ }^{124}$ In practice, however, the CCP exercises governance over China parallel to official State governing bodies. ${ }^{125}$ The CCP Committee also exerts tremendous influence at all levels of the court system. ${ }^{126}$ The Committee often selects judges, and the People's Congress at the corresponding level ratifies its choices. ${ }^{127}$ These judges go on to serve on the adjudication committee of each court, wielding considerable power in determining the outcome of controversial cases. ${ }^{128}$ Judges who are also CCP members sometimes discuss cases involving difficult legal issues with the Political-Legal Committee and accept general policies set by the CCP. ${ }^{129}$

Judges in China do not enjoy independent judicial decision-making. The government appoints judges, pays them a low salary, and does not grant them tenure. ${ }^{130}$ The low salaries and financial dependence on the government could increase the instances of judges accepting bribes or favoring local parties. ${ }^{131}$ In addition, judges' relatives and administrative superiors may influence their judicial decision-making. ${ }^{132}$

Corruption has often been cited as a deeply rooted problem in the Chinese court system. One judge reported that she refused a large number of bribes and banquet invitations, and as a result "was ridiculed by her neighbors, treated coldly by her friends and was even the object of revenge and abuse by scoundrels, but in the end ... won the trust and praise of the masses."133

Courts in China have less power than their western counterparts, partly due to the current constitutional structure. Judges are appointed by local People's Congresses and are funded by local governments. ${ }^{134}$ The judges rely on salaries and housing provided by the municipal government. ${ }^{135}$ This dependence can give local governments leverage over the courts, and government officials have been known to make threats such as cutting off

124. James V. Feinerman, The Give and Take of Central-Local Relations, CHINA Bus. REV., Jan. 1, 1998.

125. Id.

126. Randall Peerenboom, China's long March Toward Rule of law 302 (Cambridge University Press 2002) [hereinafter LONG MARCH].

127. Id. at 305-306.

128. Id. at 306 .

129. Id. at 306-307.

130. BIRD IN A CAGE, supra note 16, at 252, 279; LONG MARCH, supra note 126, at 294.

131. Interview with Zhao Shiyan, supra note 27.

132. BIRD IN A CAGE, supra note 16, at 278; Interview with Zhao Shiyan, supra note 27.

133. BIRD IN A CAGE, supra note 16, at 279.

134. Id. at $252,256$.

135. Id. at 264 . 
needed funding to build housing for court staff. ${ }^{136}$ Local courts might "choose" to protect the defendant business or government to safeguard the local financial needs of the courts or the government. ${ }^{137}$

Courts are also more dependent on local government due to a gradual decentralization that has taken place since 1985 . $^{138}$ Local governments must often support themselves through local taxes, fees and charges collected from local businesses, creating an incentive for the court to propagate those steady sources of income. ${ }^{139}$ The enforcement of an arbitration award against a local business could thus negatively impact the local economy and, in some cases, cause the business to shut down, resulting in a number of citizens losing their jobs and housing. ${ }^{140}$ Local People's Courts recognize these detrimental effects and may seek to evade enforcement of the award. ${ }^{141}$

Decentralization has also affected the various levels of sophistication found within the local court systems. Provinces develop and adopt new regulations promulgated by the central government at different speeds, influencing the chances of effectuating enforcement of an award. Dean Wang Chenguang, notes that the court systems in the coastal areas are more highly developed, as lawyers trained in those areas tend to stay there to work. Thus, the level of education for judges and lawyers involved in the system is raised, and typically more interaction occurs with foreign parties. ${ }^{142}$ On the other hand, rural areas often suffer a high attrition rate because many students move to the large cities to pursue a higher education, leaving a court system illprepared to handle conflicts with foreigners. ${ }^{143}$

\section{E. Local Protectionism}

Local protectionism has long been a problem in China. In an effort to fight protectionism, imperial China required its magistrates to rotate to new places every few years and prohibited them from serving in their home

136. Id.

137. Cecimia Hákansson Commercial ARbitration Under Chinese Law 198 (Iustus Förlag 1999).

138. Id. at 198.; See also Pitman B. Potter, Legal Reform in China: Institutions, Culture, and Selective Adaptation, 29 LAW \& Soc. INQUIRY 465, 473 (2004) (noting that this interplay of central and subnational governments resembles the federalist system of the United States).

139. HAKANSSON, supra note 137, at 198.

140. Id.

141. Id.; But see Seek Truth, supra note 120, at 277 (challenging the theory of higher enforcement in more sophisticated areas by finding more instances of local protectionism in major investment centers than in smaller cities).

142. See Interview with Wang Chenguang, supra note 19.

143. Id. Indeed, Wang Chenguang indicates the Supreme People's Court is considering whether to effectuate simpler court procedures in outlying areas to make the systems more accessible to the public and easier to use. 
districts. ${ }^{144}$ Local protectionism can appear at any stage in the judicial process, and it affects both foreign parties and parties from foreign provinces in China. Judges have required applicants who are seeking enforcement of arbitral awards to provide a number of documents not required by PRC law, including evidentiary documents that the arbitration tribunals relied on in making the awards. ${ }^{145}$ Judges have also required parties to perform the costly and timeconsuming effort of translating, notarizing, and consularizing the documents. ${ }^{146}$

In one form of protectionism, local governments may help companies to hide or transfer assets or dodge debts. ${ }^{147}$ This appears to have taken place in the infamous RevPower case, where RevPower Limited received a $\$ 9$ million arbitral award from the Stockholm Chamber of Commerce against a Chinese party. When RevPower attempted to enforce the award in the Shanghai People's Court, the court refused to acknowledge the award for two years, during which time the Chinese party had transferred its business and assets to its parent and grandparent companies, thus appearing to be insolvent. ${ }^{148}$

Chinese authorities recognize that local protectionism adversely affects long-term business dealings with foreign companies. One Chinese report stated, "[T]he hard-won respect of CIETAC is being squandered by a judicial system unable to make Chinese parties pay up." 149 In 1991, the President of the SPC, Ren Jianxin, acknowledged to the NPC the damage caused by local protectionism. He urged several prohibitions to counter local protectionism:

(i) prohibiting local party cadres from interfering with the judicial process in an attempt to protect local interests;

(ii) prohibiting government officials and other parties from making threats or launching campaigns against judicial officers carrying out the execution of court orders;

(iii) prohibiting judicial organs from practicing favoritism towards local parties by making unfair rulings or avoiding their proper responsibilities;

(iv) prohibiting officials of the public security and procuratorial organs from interfering with the adjudication of

144. See First Public Hearing of the US-China Comm'n, (D.C. June 14, 2001) [hereinafter U.S.-China Comm'n Hearing].

145. See Seek Truth, supra note 120 , at 299 , n.178.

146. See Evolving Regulatory Framework, supra note 31, at 19.

147. Id. at 46.

148. See Brown \& Rodgers, supra note 24, at 341-42; Seek Truth, supra note 120, at 250, n.5.

149. See Stanley B. Lubman \& Gregory C. Wajnowski, International Commercial Dispute Resolution in China: A Practical Assessment, 4 AM. REv. INT'L ARB. 107, 157 (1993) (quoting Matthew D. Bersani, The Enforcement of Arbitration Awards in China, 10(2) J. INT'L ARB. 47, 49 (1993)). 
economic cases by treating contract and debt disputes as offences; and

(v) prohibiting any organ or individual from obstructing the execution orders of the People's Courts in any other way. ${ }^{150}$

Justice Ren urged that court personnel and government officials who repeatedly violate these prohibitions and engage in local protectionism be disciplined and possibly subject to criminal sanctions.

While the SPC has responded to the threat of local protectionism, as discussed later in this Article, it is uncertain whether these efforts have had an effect. The web site for the BAC contains an interesting editorial note concerning the continuing threat of local protectionism in relation to Chinese parties from outlying provinces. The editor writes:

When I attended an international convention, hearing other countries talk about the severe regional protectionism of China Mainland justice, a so-called national self-respect made me hardly admitted [sic] I had heard about willingly and promptly even though I did not believed [sic] it to be absolutely unreasonable and irresponsible. Upon reading the following cases however, I was dropped into such agony that [the] ghost of the regional protectionism [was] broadening its magic trace around Chinese great ground. ${ }^{151}$

The situation is certainly alive and well, and it remains to be fully addressed.

\section{F. Transfer of Assets and Resulting Insolvency of Chinese Party}

\section{Assistance of Courts, Officials}

Peerenboom disagrees with critics who blame local protectionism for the lack of enforcement of awards. Instead he claims local protectionism has served as a scapegoat for judges, central government officials, and lawyers, where blame for failure to enforce the award is shifted to local government officials. $^{152}$ Peerenboom argues that the true challenge of enforcing an arbitration award is the insolvency of the respondent. ${ }^{153}$ Of the thirty-seven

150. See Cheng DeJun, supra note 115 , at 128 .

151. See Civil Ruling of Shanxi Jiexiu People's Court Against Enforcement of No. 199801276 Arbitration Award of Beijing Arbitration Commission, at http://www.bjac.org.cn/en/brow.asp?id=145 (last visited Sept. 29, 2005).

152. See Seek Truth, supra note 120, at 276.

153. Id. at 254. 
non-enforcement cases in his 1997 survey, forty-three percent were unenforceable because the respondent did not have the necessary assets to pay the award. 154 In eleven of the sixteen no-asset non-enforcement cases, local counsel for the petitioners believed that the respondents were truly insolvent and lacked unencumbered assets. ${ }^{155}$ In three other cases, the lawyers believed the respondents had fraudulently transferred their assets to other companies to avoid payment. The lawyers in the remaining two cases were unsure whether the respondent had assets. ${ }^{156}$

While Peerenboom downplays the role of local protectionism in the enforcement of awards, many cases of apparent insolvency could be a result of protectionism. For example, a local government official could warn a company of an upcoming application for enforcement, leading to a fraudulent transfer. Or a bank might aid the local party by delaying or refusing to provide bank account information or by freezing bank accounts.

If the property has been transferred or is no longer available, the plaintiff might need to bring a second suit to seize property to satisfy the award. For example, Wang Chenguang served as chief arbitrator in a case in Shenzhen. ${ }^{157}$ Wang later spoke with the attorney of the winning party who said the enforcement was taking a long time because the other party had declared bankruptcy. ${ }^{158}$ As a result, the attorney had to file another lawsuit to seize property in order to satisfy the award. ${ }^{159}$

An additional lawsuit was also necessary in the case of Guangzhou Ocean Shipping Company, in which the defendant American company failed to pay the remainder of an arbitration award. ${ }^{160}$ The plaintiff Chinese company learned that a third party, located in China, owed the defendant a freight fee and was preparing to pay the fee. ${ }^{161}$ The plaintiff submitted an application for recognition of the arbitral award and for a transfer of the above payment to the plaintiff to satisfy that award. The Guangzhou Maritime Court ordered the fee to be paid directly to the plaintiff. ${ }^{162}$

\section{Applicants Have the Responsibility to Locate Respondents' Assets for Collection}

In order to attach assets, courts must ascertain where the assets are located. Respondents are required by law to state the location of their assets;

154. Id. at $254,273$.

155. Id. at 274.

156. Id. at 274.

157. See Interview with Wang Chenguang, supra note 19.

158. Id.

159. Id.

160. See Zhao Shiyan, Enforcement of Foreign Arbitral Awards in the People's Republic of China 22 (2001) (unpublished LL.M. thesis, Vrije University, Amsterdam).

161. Id.

162. Id. 
yet in practice, parties seeking enforcement bear the burden of providing this information to the courts. ${ }^{163}$ Judges may decline to track down the assets for several reasons. They frequently have difficulty obtaining cooperation from banks and administrative agencies, due mainly to the low stature of the courts within the political structure. Banks may resist court orders to assist in enforcement because "the court is essentially just another bureaucracy, with no more power to tell [them] what to do than the Post Office." 164

In the face of frequent mergers, reorganizations, and spin-off companies, China's rapidly changing economic landscape makes it difficult to determine asset ownership. ${ }^{165}$ Inadequately documented transfers and mergers of various companies, as well as a rapidly-changing regulatory framework for land acquisition in China, have further added to the difficulty in finding clear title to many assets. ${ }^{166}$

With the burden on the applicant, information regarding the respondent's assets is even harder to obtain. Parties may have to work with professional investigation companies, whose members rely on connections with former ministry colleagues to find information on assets. ${ }^{167}$ Under PRC law, Chinese companies are limited to one bank account for normal business activities, ${ }^{168}$ yet some companies ignore this law and open multiple accounts to evade taxes. ${ }^{169}$ It is often almost impossible to track down all of a company's accounts. ${ }^{170}$

Applicants seeking information on a respondent's assets may contact the Administration of Industry and Commerce (AIC). The AIC compiles a Registration Record Book, in which all companies' financial statements should be available. ${ }^{171}$ These records are officially available to the public, but in practice they are closely guarded, and lawyers usually need to present a court notice before being granted access to the record books. ${ }^{172}$

Banks, for the most part, are reluctant to give out account information for fear of damaging relations with their customers. ${ }^{173}$ Instead of immediately complying with a court order, banks might notify customers first to allow sufficient time for the customer to transfer money into another account before the bank attempts attachment. ${ }^{174}$

163. See Seek Truth, supra note 120 , at 292.

164. Seek Truth, supra note 120, at 294 (quoting Clarke, Power and Politics in the Chinese Court System: The Enforcement of Civil Judgments, 10 COLUM. J. ASIAN L. 1, 56 (1996)).

165. See Evolving Regulatory Framework, supra note 31, at 61.

166. Id. at 63.

167. See Seek Truth supra note 120 , at 292.

168. See Commercial Banking Law of the PRC art. 48.

169. Id.

170. See Evolving Regulatory Framework, supra note 31, at 61.

171. Id.

172. Id.

173. Id.

174. Id. 


\section{G. Ambiguity in the CPL Regarding Grounds for Refusal of Enforcement}

Article 260 of the Civil Procedure Law of the People's Republic of China (for Trial Implementation) (CPL) provides specific procedural grounds for refusing to enforce foreign-related awards:

(a) the parties have neither included an arbitration clause in their contract or subsequently reached a written agreement;

(b) the respondent did not receive notification to appoint an arbitrator or to take part in the arbitration proceedings or the respondent could not state his opinions due to reasons for which he is not responsible;

(c) the formation of the arbitration tribunal or the arbitration proceedings do not conform to the rules of arbitration;

(d) the matter decided in the award exceeds the scope of the arbitration agreement or is beyond the authority of the arbitration institution.

Finally, a court may refuse to enforce an award if the enforcement is contrary to social public interests.

This final basis of refusal, where enforcement is contrary to the "social and public interests of China," could be problematic. ${ }^{175}$ In the famous case Dongfeng Garments Factory v. Henan Garments Import \& Export Co., plaintiffs alleged that the defendant had breached the parties' joint venture contract. ${ }^{176}$ A CIETAC arbitral tribunal accepted the case in April 1991 and awarded considerable damages to the plaintiffs in April 1992. The defendants did not pay the damages, so the plaintiffs commenced proceedings in an Intermediate People's Court for enforcement of the award. The court issued an order rejecting the plaintiffs' application. ${ }^{177}$ The court held that "according to current State policies and regulations, enforcement . . . would seriously harm the economic influence of the State and public interest of the society and adversely affect the foreign trade order of the State." To compel the defendant to pay damages for its breach would disadvantage "social and public interests." 178

The SPC subsequently overturned the lower court's decision in November 1992, holding "[I]t was incorrect for the Zhengzhou Municipal Intermediate People's Court to refuse to enforce the arbitral award on the

175. See HAKANSSON, supra note 137, at 203.

176. Id.

177. Id.

178. Id. 
grounds that enforcement would seriously harm the economic interests of the state."179

\section{H. Lack of Court Funds}

Court personnel must often travel to the non-performing party's local court to coordinate enforcement efforts and, lacking funds to do so themselves, they sometimes ask foreign parties to cover travel costs. However, many foreign parties would be punished in their home country if they were to comply with this request. American parties, for example, might be punished under United States law relating to corrupt overseas business practices if they give money to court personnel. ${ }^{180}$ But if the parties refuse to comply, the court could delay or refuse to enforce the award. ${ }^{181}$

\section{Shortage of Qualified, Experienced Judges}

While there are over 200,000 judges in China, most of these judges have not earned a law degree. ${ }^{182}$ Many have come to the courts after serving in the military or for Party organizations. ${ }^{183}$ As of 1993, only two-thirds of all judges had post-secondary training in any subject, including non-legal subjects. ${ }^{184}$ Furthermore, many young judges have been appointed to handle the recent judicial reforms, but they often lack the expertise required to effectuate the reforms. ${ }^{185}$ This lack of legal expertise has resulted in a mishandling of applications for enforcement of arbitration awards. ${ }^{186}$ Chinese judges may mistakenly apply PRC law to interpret the validity of an arbitration agreement, as happened in the Revpower case. ${ }^{187}$

Low salaries have exacerbated the shortage of skilled judges in China. Some of the highest-paid judges receive only RMB 2,000-3,000 Yuan per month (approximately USD 250-350 per month), whereas lawyers in China may earn RMB 10,000-30,000 Yuan per month (USD 1,200-3,600 per month), ${ }^{188}$ so judges often abandon their post for the "greener pastures" of starting their own practice or joining large firms. ${ }^{189}$ One SPC judge commented

179. See Cheng DeJun, supra note 115 , at 131 .

180. See Brown \& Rodgers, supra note 24 , at $\mathbf{n} .86$.

181. Id.

182. Susan Finder, Inside the People's Courts: China's Litigation System and the Resolution of Commercial Disputes, in DISPUTE RESOLUTION IN THE PRC: A PRACTICAL GUIDE To Litigation AND ARBITRATION IN ChINA 68 (Asia Law \& Practice Ltd. 1992).

183. Id.

184. Berkman, supra note 88, at 26.

185. Id.

186. See HAKANSSON, supra note 137, at 194.

187. See Seek Truth, supra note 120 , at 250, n.5.

188. HÅKANSSON supra note 137, at 195.

189. See Interview with Zhao Shiyan, supra note 27. 
that in 1998-1999 alone, approximately fifteen percent of all People's Court judges left their positions for positions in law firms. ${ }^{190}$

\section{J. Failure to Sanction Noncompliant Parties}

Chinese courts have a range of contempt powers to sanction those who fail to comply with the terms of a court order or obstruct the enforcement process. ${ }^{191}$ On August 23, 2002, the People's Congress adopted an interpretation of law imposing criminal sanctions on parties that attempt to evade enforcement of court judgments and arbitral awards. ${ }^{192}$ In addition, Article 102 of the CPL prohibits forging or destroying important evidence; concealing, transferring, selling, or destroying property that has been sealed up or detained; and refusing to carry out legally effective judgments or orders of the people's court. ${ }^{193}$ Under Article 104, courts may impose fines between RMB 1,000 and 30,000 on non-compliant companies and impose punitive damages in the amount of twice the interest from the time of default. ${ }^{194}$

In addition to financial sanctions, courts may detain respondents for refusing to comply with subpoenas. Article 313 of the Criminal Law ${ }^{195}$ gives courts the ability to impose a sentence of less than three years on parties that seek to conceal, transfer, or intentionally destroy property, as well as voluntarily convey property or transfer property at an unreasonably low price, making the judgment or award unenforceable. ${ }^{196}$ Under Article 221 of the CPL, courts may freeze or transfer the bank deposits of the losing party, as well as make inquiries to banks or other financial institutions. ${ }^{197}$ Courts may also withhold or garnish wages or evict a respondent from his home under Article 222 of the CPL. ${ }^{198}$

With this wide array of sanction possibilities, one might expect Chinese courts to effectively control non-compliance. ${ }^{199}$ But the measures are not often utilized and have sometimes proven ineffective. ${ }^{200}$ According to Judge Lu

190. Id.

191. See Evolving Regulatory Framework, supra note 31, at 50-51.

192. Wang Sheng Chang, Roundtable on Arbitration and Conciliation Concerning China: CIETAC's Perspective 6 (paper presented at 17th ICCA Conference, May 16-18, 2004) [hereinafter Roundtable: CIETAC'S Perspective].

193. CPL art. 102.

194. See Evolving Regulatory Framework, supra note 31, at 51 .

195. Effective October 1, 1997. But according to Jeffrey Berkman, Chinese judges do not have the authority to issue criminal contempt orders. See Berkman, supra note 88, at 25.

196. See Roundtable: CIETAC's Perspective, supra note 192, at 6.

197. Evolving Regulatory Framework, supra note 31, at 53, n.228.

198. Id. at 53, n.231.

199. Wang Sheng Chang, the Vice Chairman \& Secretary General of CIETAC, stated, "It is expected that the law interpretation will extend a considerable assistance to curb the bad faith behavior attempting to evade the enforcement." Roundtable: CIETAC's Perspective, supra note 192 , at 6.

200. Evolving Regulatory Framework, supra note 31, at 53. 
Xiaolong of the Supreme People's Court, the SPC has never sanctioned noncompliant parties for not paying a damages award and has never held a noncompliant party in contempt of court. ${ }^{201}$

Local government officials may instruct managers of the respondent company to not comply with the court's orders. Because of the low stature of Chinese courts and lack of respect for the rule of law, judges fear their imposed fines or detention of non-complying officials will not be carried out. ${ }^{202}$

Courts might instead take creative extra-judicial measures to effect compliance. Some courts have had the name of a non-complying company published in the local newspaper. ${ }^{203}$ This effectively puts pressure on the defaulting company to pay up, while providing notice to other companies of the defaulting company's potentially poor economic condition. ${ }^{204}$

\section{K. Lack of Transparency in Judicial Process}

Parties often have difficulty determining what actually happened during the enforcement proceedings, as they do not have a right to participate in hearings where higher courts decide whether or not to enforce an arbitration award. ${ }^{205}$ The higher court need not notify the parties about the hearing or give them an opportunity to submit written documents to support their positions. ${ }^{206}$ Some parties have complained that the higher court's reliance on the lower court's presentation of the facts and legal issues disadvantaged them. ${ }^{207}$ Furthermore, the Enforcement Regulation does not require that the court state the reason for its decision or state the grounds for deciding to extend the allotted time for enforcement. ${ }^{208}$

\section{What STEPS Has CHINA TAKEN TO ENSURE ENFORCEMENT?}

Considering the infancy of the legal system and arbitration commissions in China, as well as the constitutional obstacles facing courts, Chinese officials and judges are attempting to change the current system to better enforce arbitration awards and allow foreign investors to feel safe when conducting business transactions. This section will analyze recent developments in award enforcement.

201. E-mail from Dr. Lu Xiaolong, Judge, Supreme People's Court, China (Jan. 19, 2005, 08:41 PST) (on file with author). Dr. Xiolong is the head of the SPC tribunal which reviews cases referred by the reporting mechanism.

202. Evolving Regulatory Framework, supra note 31, at 53.

203. Id. at 54 .

204. Chinese law practitioners appear well-versed in using all resources, not just legal ones. As one Chinese attorney stated, one needs to "think of a problem in a less legal way!" Interview with Zhao Shiyan, supra note 27.

205. See Seek Truth, supra note 120, at 288.

206. Id.

207. Id.

208. Id. at 289. 


\section{A. Party Members and Government Officials Are Speaking Up}

Many top leaders in the Chinese government recognize the importance of attracting foreign investment and are aware of the adverse effects of negative publicity resulting from cases such as Revpower. ${ }^{209}$ As a result, the government has passed several laws that provide foreign investors with benefits and protection not given to domestic companies. ${ }^{210}$ The CCP has supported government efforts to combat local protectionism through campaigns such as designating 1999 to be the "Year of Enforcement."211 The CCP is not supposed to interfere with courts to influence the outcome of cases. Nevertheless, judges (often CCP members) continue to discuss specific cases with the CCP PoliticalLegal Committee. Furthermore, the "flurry of rule-making" by the Supreme People's Court, described below, can be seen as "testimony to the resolve of the Chinese Government to come to grips with this important matter."212

Indeed, Peerenboom concluded that Party interference did not affect enforcement of arbitral awards. ${ }^{213}$ He found only one case where a party member blocked the enforcement of an arbitral award, and he reported that most lawyers surveyed felt that the CCP played a positive role in award enforcement. $^{214}$ Senior leaders attempting to attract foreign investment do not want the negative publicity that results from awards that are not enforced. ${ }^{215}$ Peerenboom cited three cases where a senior member of the CCP Committee or the Political-Legal Committee helped secure enforcement. ${ }^{216}$

The bigger tension in China may arise between political and legal reform. Due to the authoritarian nature of a one-party regime, the Chinese government might feel that it cannot afford to lose cases. The government wants freedom of contract, yet it has not demonstrated its willingness to lose some cases and subject itself to the legal system. Without surrendering control over court decisions, it will be very difficult "to create a market economy that will inspire the confidence of foreign financial investors.",217

\section{B. Statutory Interpretations Passed by the SPC}

Neither Arbitration Law nor Civil Procedure Law contain procedural rules for enforcing arbitral awards or challenging the validity of arbitration

209. See Seek Truth, supra note 120 , at 279-280, 320-321.

210. Id.

211. Seek Truth, supra note 120, at 285. One source stated that the Year of Enforcement was actually proposed by the SPC, but embraced by government officials. Claver-Carone, supra note 75 , at 392, n. 157 .

212. See Roundtable, supra note 61 , at 11.

213. See Seek Truth, supra note 120, at 285.

214. Id. at 286.

215. Id.

216. Id.

217. See US-China Comm'n Hearing, supra note 144, at 5. 
agreements. $^{218}$ These issues are instead addressed in several dozen judicial notices. $^{219}$ The most important of these notices are discussed below.

\section{1995 SPC Reporting Mechanism Notice}

"In 1995, the SPC issued the Notice on Courts' Handling of Issues in Relation to Matters of Foreign-related Arbitration and Foreign Arbitration (1995 Notice)."220 The Notice specifies that, if an IPC intends to refuse to recognize or enforce a foreign award, it must first submit a report to the Higher People's Court (HPC). If the HPC agrees with the IPC, the HPC must then report the case to the SPC. ${ }^{221}$ The SPC has a special tribunal to review these cases. The tribunal reviews the validity of arbitral clauses or agreements and the resulting awards in both domestic and foreign-related arbitrations. ${ }^{222}$

The SPC generally reviews about 30 cases every year, although in 2004 it reviewed over 40 cases. $^{223}$ These cases result in either enforcement of the award or refusal to enforce. ${ }^{24}$ Supreme People's Court Judge Zhang Jin Xian related two recent examples of SPC review under the reporting mechanism. ${ }^{225}$ In one case, the London Sugar Association sought to have an arbitral award enforced against the China Sugar \& Wine Group Company before the Beijing No. 1 Intermediate People's Court. ${ }^{226}$ In a decree issued on August 6, 2001, the court refused to recognize and enforce the award, stating the award ran counter to public policy in China. On appeal, the Beijing High People's Court affirmed this decision. The case was then reviewed by the Supreme People's Court. In a decision on July 1, 2003, the SPC recognized and enforced the award, holding that while the transaction leading to the award was invalid according to Chinese law, the action was not equal to violating the public policy of China. ${ }^{227}$

In another recent case, the London Arbitration Tribunal granted an award on December 7, 2001 for contract violation against Wuhu Smeltery, Anhui, China, on behalf of Gerald Metals Inc. (GMI). ${ }^{228}$ GMI sought to have the award enforced before the Anhui Province Higher People's Court, but the court found that the award went beyond the scope of the arbitration clause included

218. See Roundtable, supra note 61 , at 9 .

219. Id.; See also Lu Xiaolong, The Recognition and Enforcement of Foreign Arbitral Award in China, Address at the 17th ICCA Conference (May 16-8, 2004).

220. Evolving Regulatory Framework, supra note 31, at 9.

221. ChENG DeJUN, supra note 115, at 128.

222. E-mail from Dr. Lu Xiaolong, Judge, Supreme People's Court, China (Jan. 19, 2005, 08:41 PST) (on file with author). Dr. Xiolong is the head of the SPC tribunal which reviews cases referred by the reporting mechanism.

223. Id.

224. Id.

225. E-mail from Zhang Jin Xian, Judge, Supreme People's Court, China (Jan. 25, 2005, 04:36 PST) (on file with author).

226. Id.

227. Id.

228. Id. 
in the contract and refused to recognize the entire award. ${ }^{229}$ On review, the SPC affirmed that the award went beyond the scope of the arbitration clause, but it found that the award could be separated into two parts: the section with the right to arbitrate and the section not under arbitration. ${ }^{230}$ The SPC concluded that part of the award arose from the arbitrable section of the contract, and it recognized that portion of the award. ${ }^{231}$

\section{Interim Preservation of Assets and Evidence}

To prevent funds from being transferred for the purpose of evading enforcement of an arbitration award, a party may apply to the arbitration commission for preservation of the other party's assets. The arbitration commission must then file a request with the People's Court, as per Article 28 of the Arbitration Law. ${ }^{232}$ A party can also move for property preservation under Article 258 of the Civil Procedure Law. ${ }^{233}$ The People's Court then rules on the request for interim intervention. ${ }^{234}$

While these provisions certainly indicate a willingness by the court system to preserve property, these methods may fail for the same reasons discussed above; the same local court ruling on the interim request could have already facilitated local protectionism. As previously stated, the local court may deny the application out of fear that enforcement might interfere with the defendant's ability to operate a company or in response to pressure from local governments.

\section{1998 Regulation Clarifying Arbitration Fees and Establishing Time Limitations}

In 1998, the SPC issued the Regulations of the SPC Regarding the Issues of Fees and Investigation Periods for the Recognition and Enforcement of Foreign Arbitral Awards ("Regulations"). ${ }^{235}$ These Regulations clarified the standards regarding collection of fees for actions to enforce foreign arbitral awards and suggested time limitations within which courts should resolve such actions. $^{236}$ The Regulations apply nationwide, specifying that the People's Courts may collect an application fee of 500 yuan for each action. ${ }^{237}$ In addition, the court may require that the party applying for enforcement of an

229. Id.

230. Id.

231. Id.

232. E-mail from Cao Lijun, Arbitrator and Staff Member of CIETAC, Beijing, China (Dec. 10, 2004, 02:04 PST) (on file with author) [hereinafter Cao Lijun e-mail (12/10/04)].

233. Id.

234. See HAKANSSON , supra note 142 , at 145.

235. CHENG Dejun, supra note 115 , at 137.

236. Id.

237. Id. 
arbitral award pay an enforcement fee in advance, the amount of which is determined in accordance with the fee scale contained in the Measures Regarding Costs for People's Court Actions promulgated in 1989. ${ }^{238}$ The Regulations thus prohibited the common practice of "double collection," where People's Courts charged parties separately for recognition and enforcement procedures. ${ }^{239}$

The Regulations also addressed "judicial purgatory" in handling applications for the recognition and enforcement of foreign arbitral awards. ${ }^{240}$ Under the Regulations, the People's Court must issue its ruling within two months from the date of accepting the application. ${ }^{241}$ Then the court must complete the enforcement proceedings within six months of the ruling granting recognition of the award. ${ }^{242}$ If the court refuses recognition or enforcement, it must report to the SPC within two months from the date it accepted the application. ${ }^{243}$

\section{1998 Education Rectification Campaign}

Xiao Yang, the President of the SPC, reportedly confirmed comments by President Jiang Zemin that law enforcement officials have participated in such wrongs as "eating free meals, taking without paying, imposing man-made barriers and soliciting favors, demanding and taking bribes, perverting justice for money, and bullying the common people ...."244 In 1998, Chinese officials responded by ordering an "educational rectification campaign" that denounced these activities and focused on reducing judicial corruption, incompetence and inefficiency. As a result, 8,110 previously mishandled cases were corrected, and nearly 5,000 judges and prosecutors were disciplined. ${ }^{245}$

\section{2002 and 2003 SPC Regulations Limiting Jurisdiction Over} Arbitration Awards with Foreign Elements to Specialized IPC Courts

On March 1, 2002, the SPC issued a directive stating that all civil and commercial cases involving foreign elements are under the jurisdiction of specific IPCs in capital cities of provinces and special economic zones. ${ }^{246}$ This provision was handed down with the intent to lessen the potential local

238. Id.

239. Id. at 138.

240. Id.

241. Id.

242. Id.

243. Id.

244. Randall Peerenboom, Globalization, Path Dependency and the Limits of Law: Administrative Law Reform and Rule of Law in the People's Republic of China, 19 BERKELEY J. INT'L L. 161, 264 n.369 (2001).

245. Id.

246. See Xiaolong, supra note 219. The SPC solidified this rule in its Dec. 31, 2003, provisions. 
protectionism of local courts, particularly protectionism aimed at foreign parties. $^{247}$ The SPC also intended to increase the quality of judgment by focusing foreign-element cases in courts with highly-educated and experienced judges. ${ }^{248}$

It is too soon to say whether this interpretation has reduced the local protectionism faced by foreign parties, both from other provinces and from other countries. SPC Judge Zhang believes that the interpretation has improved the Chinese legal environment. As an example, he cites to the Intermediate People's Courts in Guangdong province, which tried ten cases between foreign parties and local governments from 2002 to 2004. Judge Zhang claims that, due to the 2002 interpretation, the local government defendants were discouraged from interfering in the judicial process. The fact that none of the parties appealed the decisions provides evidence that the cases were decided fairly. ${ }^{249}$

\section{SPC Regulation Imposing Liability for Failure to Enforce Awards}

In 2000, the SPC issued two regulations to clarify jurisdictional issues and increase the sense of responsibility among enforcement personnel. ${ }^{250}$ The regulations imposed liability for failure to enforce judgments and awards in accordance with the law. ${ }^{251}$ However, the likelihood of judges using these regulations remains to be seen, particularly given the courts' current lack of interest in sanctions.

\section{1995 Judges Law}

China now requires a basic standard of education for its judges. The 1995 Judges Law specifies that judges must be graduates of tertiary educational institutions in law or have specialized legal knowledge. ${ }^{252}$ Judges appointed $^{2}$ before the implementation of the Judges Law who do not meet these standards must attend a "Judges' College" to study law part-time. ${ }^{253}$ The SPC has trained HPC judges at the National Judges Institute, and those judges are responsible for training other judges. ${ }^{254}$ The SPC has provided specific training for judges on enforcement. ${ }^{255}$

247. Id.

248. See Rountable, supra note 61 , at 11.

249. See Zhang Jin Xian, supra note 225.

250. Evolving Regulatory Framework, supra note 31, at 6.

251. Id.

252. Finder, supra note 182, at 68.

253. See id.

254. LONG MARCH, supra note 126, at 293.

255. See Finder, supra note 182. 


\section{Changes in CIETAC Arbitration Rules}

CIETAC made a series of major changes to its arbitration rules in 1994, 1995 , and 1998, bringing them more in line with recognized international standards. ${ }^{256}$ CIETAC now permits foreign arbitrators to be included in the Panel of Arbitrators. ${ }^{257}$ Arbitration can be carried out in English or other foreign languages, as agreed upon by the parties involved. ${ }^{258}$ Foreign parties can also use their own non-Chinese attorneys in the proceedings. ${ }^{259}$ The new arbitration rules set forth a nine-month time limit for a tribunal to conduct a hearing and render its award, although time extensions may be granted. ${ }^{260}$ Arbitral awards are final and binding upon both disputing parties. Neither party may bring suit before a court or request alteration of the award from any other organization. ${ }^{261}$

The revised CIETAC rules now provide for new "fast-track" arbitration tribunals. In the "fast track," a single arbitrator appointed by the CIETAC chairman handles claims worth less than RMB 500,000 yuan (USD 60,000). ${ }^{262}$ Under these proceedings, "[o]ral hearings need not take place."263 The panel must render an award within ninety days from the appointment of the arbitrator or within thirty days from the conclusion of an oral hearing. ${ }^{264}$ This type of tribunal particularly benefits parties with smaller claims and parties with time constraints.

\section{FURTHER SUGGESTIONS TO ASSIST ENFORCEMENT OF CHINESE ARBITRATION AWARDS}

It is not yet clear whether the newly-promulgated SPC rules are having much impact on the enforcement of awards. Professor Jerome Cohen describes these measures as "band-aids for a patient that is severely ill," while the system needs "radical surgery and structural rehabilitation." ${ }^{265}$ It is true that band-aids are easier to apply in China than larger, overarching structural transformations. ${ }^{266}$ After all, China does not take quickly to changes, especially those changes that might threaten the primacy of the CCP. However, a

256. Ge, supra note 2, at 131-2.

257. See CIETAC Arbitration Rules, Art. 10.

258. See id. at Art. 85.

259. See id. at Art. 22.

260. See id. at Art. 52.

261. See id. at Art. 60.

262. See Ge, supra note 2, at 133.

263. Id.

264. Id.

265. Jerome Cohen, Opening Statement Before the First Public Hearing of the U.S.-China Commission, (June 14, 2001) available at http://www.uscc.gov/hearings/2001_02hearings/transcripts/01_06_14tran.pdf (hereinafter USChina Commission Hearing).

266. See Interview with Wang Chenguang, supra note 19. 
combination of several additional "quick fixes" and deeper structural changes should help modify the current system and reassure foreign investors that they can ultimately achieve a happy ending in China.

\section{A. Publish Comprehensive Statistics on Enforcement}

Scholars and practitioners have urged the Chinese government to make Chinese arbitration more public and transparent. As a result, two volumes have been published containing written CIETAC awards. ${ }^{267}$ These volumes help add transparency to the CIETAC process. In addition, Cheng Dejun and Wang Sheng Chang, both Vice Chairmen of CIETAC, and Michael Moser, a CIETAC arbitrator, published various case summaries in their recent volume "International Arbitration in the People's Republic of China: Commentary, Cases and Materials" (2nd ed. 2000).

While these publications are useful in introducing practitioners to CIETAC practices, ${ }^{268}$ their helpfulness in determining the reasoning behind CIETAC awards and the enforceability of those awards is questionable. The awards often fail to state the applicable legal rules, focusing more on the fairness or equity of the awards than on the rules themselves. ${ }^{269}$ The factspecific awards, thus, offer little guidance to lawyers seeking to determine the reasoning behind CIETAC awards. ${ }^{270}$

Nevertheless, arbitration bodies such as CIETAC are in advantageous positions to determine whether their foreign-related awards are enforced by the court system. For example, through post-arbitration questionnaires and research, CIETAC could compile a database of awards, their enforcement rates, and reasons for non-enforcement. At least one CIETAC official has recognized the importance of such statistics and has indicated CIETAC's willingness to conduct these types of surveys in the near future. ${ }^{271}$

\section{B. Continue to Improve the Education of Chinese Judges}

As discussed earlier, many Chinese judges do not have a background in law, and most have never studied foreign legal systems. The fledgling court system, low political stature, and lack of historical precedents make it difficult for judges to know and follow any rule of law.

267. See Selected Works of ChINA INTERNATIONAL ECONOMIC AND TRADE ARBITRATION COMMISSION AWARDS (1989-1995) UPDATED TO 1997 (Patricia Leung ed., Sweet \& Maxwell, 1998).

268. Id.

269. See BIRD IN A CAGE, supra note 16. This may reflect the Chinese tendency to focus more on the solution of the dispute, the fairness of the solution and the factual situation than to the legal arguments presented by the parties. Id.

270. See id.

271. See Cao Lijun e-mail (12/10/04), supra note 232. 
One recent development may assist the process of improving the legal system in China. In 1999, Temple University School of Law collaborated with Tsinghua University in Beijing to begin the first foreign LL.M. degree program in China. ${ }^{272}$ As of November 2004, 141 lawyers and judges had graduated from this program. This 15 -month, 30 credit program includes a summer semester at Temple's campus in Philadelphia. ${ }^{273}$ Combined with several other legal programs in China, Temple has educated 411 legal professionals within just four years. ${ }^{274}$

After four years of running the only Western LL.M program in China, Temple is being joined by several other Western-style law programs. The University of Minnesota Law School is currently planning an LL.M. program to begin in Summer 2005, in collaboration with China University of Political Science and Law ("Fada") in Beijing. Through this program, Chinese lawyers will earn 24 credits in an 18-month period, which will be taught in English by the University of Minnesota faculty. ${ }^{275}$ Additionally, in February 2004, Peking University Law School and the Raoul Wallenberg Institute of Human Rights and Humanitarian Law at Lund University in Sweden launched a threesemester Masters' program for Research Direction in Human Rights. ${ }^{276}$ Twenty postgraduate students from Peking University are enrolled in this groundbreaking program. $^{277}$

Several other programs in specialized legal areas have also begun in China. The University of Maryland and Tianjin University are offering a Masters degree in Judicial Justice, while the University of Australia is collaborating with Normal University in Shanghai to offer a Masters degree in International Business Transactions. ${ }^{278}$ Additionally, Chinese judges and lawyers have increasingly been permitted to study abroad. ${ }^{279}$

272. Interview with John Smagula, Director of Asia Law Programs, Temple University School of Law, in Beijing, China (Nov. 2, 2004).

273. Id.

274. Id. Temple's other programs include a judicial education partnership with the Supreme People's Court, a prosecutorial education partnership with the Supreme People's Procuratorate, legislative drafting projects, scholarly roundtables promoting the development of law, and AIDS and public health law initiatives. Id.

275. Interview with Adelaide Ferguson, Assistant Dean for Post J.D. Programs, Temple University School of Law, in Beijing, China (Nov. 6, 2004); Mary Jane Smetanka, STAR TRIB., Dec. 5, 2004, $U$ and China: $A$ shared passion for education, at http://www.startribune.com/stories/1592/51 19861.html (Published Dec. 5, 2005) (last visited Oct. 1, 2005); E-mail from Meredith M. McQuaid, Associate Dean and Director of International and Graduate Programs, University of Minnesota School of Law (Dec. 15, 2004, 14:33 PST).

276. See Interview with Adelaide Ferguson; A Brief Introduction to the Human Rights Master Program, at http://www.hrol.org/hrmp/english.php (last visited Oct. 7, 2005).

277. Id.

278. Interview with Mo Zhang, Professor, Temple University School of Law, in Beijing, China (Nov. 1, 2004).

279. For example, Temple Law School reports 20 LL.M. Chinese graduates from their main campus in Philadelphia. Johan Gernandt, Vice Chairman of the Arbitration Institute of the Stockholm Chamber of Commerce, reports that several Chinese lawyers have studied or 


\section{Develop a Special Judicial Division for Enforcement of Foreign- Related Awards}

While the SPC has already taken steps to ensure a judge's expertise in the field, namely by assigning foreign-related arbitration enforcement cases to specifically designated IPCs, the development of separate divisions specializing in enforcement of foreign-related awards will further help ensure judges' expertise and lessen local protectionism. This approach is already being tested in the intellectual property realm. Special courts dedicated to intellectual property matters were established in July 1993 as divisions of the Beijing HPC and IPC. ${ }^{280}$ Judicial personnel in these divisions receive specialized training to improve their ability to handle difficult cases. ${ }^{281}$ In a similar manner, China could develop specialized enforcement branches aimed solely at arbitration awards. This would ensure a high level of specialization within the divisions and would reassure foreign investors concerned about fairness and expertise. ${ }^{282}$

\section{Hire a Skilled Local Attorney to Help Develop "Guanxi" Relationships With Local Officials}

Attorney Zhao Shiyan notes that most of the barriers in enforcement are practical, not legal. ${ }^{283}$ Accordingly, he suggests that foreign investors make good connections with local governments and banks. If a conflict arises, Shiyan suggests that the foreign party hire a competent local attorney, sit down with bank officials (or the potentially troubling party), and talk through the problem amicably. ${ }^{284}$ Spoken like a true Confucianist, Shiyan suggests arbitration proceedings should be avoided if at all possible, and the problems should be addressed through relationships. ${ }^{285}$

practiced in Stockholm, Sweden during the last ten years. Johan Gernandt, Round Table on Arbitration and Conciliation Concerning China (paper prepared for presentation at the 17th ICCA Conf., May 17, 2004).

Furthermore, in 1997, the Solicitor-General of Hong Kong, Daniel Fung, announced the establishment of a model court in mainland China funded by the Hong Kong government, where judges and attomeys from Hong Kong would stage mock trials for observation by Chinese lawyers, judges and officials. See Interview by Kirsten Sylvester with Daniel Fung, SolicitorGeneral of Hong Kong, Washington, D.C. (1997), available at 1998 WL 10921709.

280. See Berkman, supra note 88 , at 28 .

281. Id.

282. See Kaplan, supra note 32, at 16. .Neil Kaplan has also proposed the development of specialized courts for arbitration awards: "There must be something to be said in favour of creating one body to deal with all arbitration issues coming into Chinese courts - these specialist institutions have the ability to establish consistency in their decisions."

283. See Interview with Zhao Shiyan, supra note 27.

284. Id.

285. Id. 


\section{E. Persevere}

One American academic has "diagnosed" many foreigners with "forensic xenophobia," meaning they are unwilling to use the Chinese legal system. ${ }^{286}$ He argues that foreigners should push through these "fears" and use the court system. By doing this, procedural obstacles and weaknesses in the legal code will be uncovered, continuing to alert the Chinese government of the need for further reforms. Also, the existence of several notorious cases, such as Revpower, will likely discourage local officials from utilizing protectionist methods.

\section{CONCLUSION}

China's arbitration system is a fascinating case study in the recent development of a judicial system constrained by severe social and economic factors. Foreign investors desire a guaranteed return on their investment, yet social and political factors both encourage and thwart that certainty. Additional political pressure from other world powers may further shape China's legal system. For example, China's recent membership in the WTO requires it to establish an internationally-recognized independent legal system.

In order to further economic development, Chinese officials have slowly allowed increased independence of the Chinese judiciary. The judiciary, recognizing the importance of protecting foreign investors in China, has produced quite a few directives towards the lower courts and has attempted to provide education for lower-level judges. These steps, however, can only go so far. The political status quo does not permit the rapid expansion of judicial power, protecting the ultimate superiority of the Communist regime. The education and independence necessary for increased freedom of contract may also result in increased freedom of speech and religion. Scholars and practitioners alike eagerly await the effects of the recent foreign arbitration regulations, as well as further reforms that will be adopted in the Chinese arbitration system. 